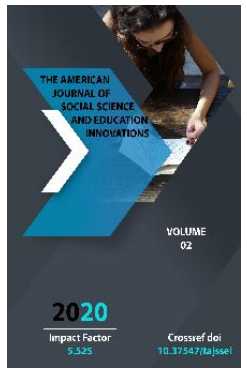

Journal Website: http://usajournalshub.c om/index,php/tajssei

Copyright: Original content from this work may be used under the terms of the creative commons attributes 4.0 licence.

\section{The Clavijo Diary Is An Important Source On The History Of} Amir Temur

\author{
Nurbayeva Feruza Yodgorbek qizi \\ Master, Faculty history, Named after Nizami TSPU, Tashkent, Uzbekistan \\ Jurayev Sunnatilla Sa'dulla o'g'li \\ Student, Faculty history, Named after Mirza Ulugbek UzNU, Tashkent, Uzbekistan \\ Aliev Islambek Jumagazievich \\ Teacher of history of the 22nd Specialized State Secondary School in Nukus, Republic of \\ Karakalpakstan, Uzbekistan
}

\title{
ABSTRACT
}

This article presents and analyzes some information about the visit of the Spanish Ambassador Rui Gonzalez de Clavijo to Samarkand and the period of Amir Temur in the diary "Journey to Samarkand Amir Temur's palace". The article also examines some of the events in the history of the Amir Temur period, historical figures and situations related to the period of Amir Temur on the basis of the Clavijo diary.

\section{KEYWORDS}

Amir Temur, Islam Karimov, diary, Samarkand, trade, ambassador, palace, king, King Henry III of Castile, Santa Maria, Ferdinand de Palasunoe.

\section{INTRODUCTION}

"Sahibkiran Amir Temur was a symbol of unparalleled courage, bravery and wisdom. This classic figure built a great empire and left a practical and theoretical legacy in the field of statehood, science, culture, creativity, religion and education. opened the way for the development, "the first President of the Republic of Uzbekistan Islam Karimov wrote in his book" High spirituality is an invincible force ". That is why it is important to study the period of Amir Temur.
The famous traveler and ambassador Rui Gonzalez de Clavijo's "Diary of a trip to Samarkand - to the palace of Amir Temur" is one of the most important works on the history of Timur. The diary contains travel memoirs of Rui Gonzalez de Clavijo, ambassador of King Henry III of Castile (Spain) (1390-1406), who lived in the palace of Amir Temur in Samarkand in 1404, in 1403-1404 he visited Turkey, Iran and Movarounnahr, especially Amir Temur is an important work that includes what he saw and knew in the 
palace. Clavijo's embassy trip to Amir Temur's country began on May 22, 1403 and in fifteen months he arrived in Samarkand. Clavijo was accompanied on this journey by Alfonso Paes de Santa Maria, Candidate of Theology, and Gomez de Salazar, the king's special guard. Clavijo's visit was in response to Amir Temur's embassy to Spain in 1402, headed by Judge Hoja Muhammad.

According to historical sources, in the 80 s and 90s of the 14th century, the fame of Timur's state reached European countries. The rulers of England, France, Spain, Genoa regularly sent ambassadors to the great Jahangir, seeking to establish political and trade relations with Amir Temur.

For example, the envoys of King Henry III of Castile, Don Pelagia de Satomatir and Don Ferdinand de Palasunoe, came to Amir Temur in 1402 when he was in Karabakh, and on July 20 of that year. Amir Temur and Boyazid I Yildirim (1389- 1402) watched the war between his armies. Ambassadors from many other countries also attended the grand postwar reception. Clavijo's embassy trip to Amir Temur was a long one, full of dangers and hardships.

\section{MATERIAL AND METODS}

In the course of the research, the history of the Amir Temur period was studied based on the "Diary of a trip to Samarkand" by the Spanish ambassador Clavijo. In the course of this research, historical, comparative analysis, periodic consistency, objectivity, and critical methods were used to cover the history of Amir Temur's period. The main purpose and direction of this research is to study and analyze the history of the period of Amir Temur on the basis of the Clavijo diary.

\section{RESULTS}

Clavijo and his companions sailed from the southeastern Spanish city of Cádiz on a sailing ship across the Mediterranean, then sailed by land through Istanbul, Trabzon, Arzirum, Tabriz, Tehran, Mashhad, Merv, and Balkh. They crossed the Amu Darya in front of Termez, came to Egypt from the villages of Samarkand on August 31, 1404 through Kesh and landed in the nearby garden of Sahibkiran. It should be noted that at that time, along with Clavijo, the ambassadors of the Sultan of Egypt and Turkey also arrived in Samarkand.

The "Diary" covers the general condition of the countries and cities under Amir Temur at that time, the living conditions of the people, buildings, palaces, mosques, madrasas, stalls, shops, workshops, built on the initiative of Timur and his relatives. the political and trade relations of the Timurid state with China, India, the Golden Horde (Clavijo calls it Tatarstan), Mongolia and other countries, the procedures in force in Timur's palace, and finally Sahibkiran's wives and noteworthy information is given about their role in the socio-political life of the country. This information will undoubtedly play an important role in the study of the history of Turkestan at that time, the way of life of our ancestors.

Now a few words about the publication and translation of the Diary. The work was first published in 1582, 150 years after its completion in Seville Spain under the title The Life and Work of Timur the Great.

200 years later, in 1782 it was republished in Madrid under the same name. The Diary was published in Spanish for the third time in 1949 in Madrid by Lopes Estrada. This book is one 
of the most important works in the history of Timur and the Timurids. The book contains travel memoirs of Rui Gonzalez de Clavijo, ambassador of King Henry III (1390-1406) of Castile (Spain), who stayed at the Timur Palace in Samarkand in 1404, in 1403-1404 in Turkey, Iran and Movarounnahr, especially in the palace of Amir Temur is an important work that contains what he sees and knows. The author of the Diary, Rui Gonzalez de Clavijo, came from a wealthy and influential aristocratic family. Both his father and he held high positions in the royal court. After the death of King Henry III (1406), he left for his hometown of Madrid and lived there for the rest of his life. Rui Gonzalez de Clavijo died in 1412 and was buried in the tomb of his ancestors in the Church of St. Francisco.

The Diary of the Spanish Ambassador Rui Gonzalez de Clavijo is of great importance in the study of the atmosphere and order in the palace of Amir Temur. Clavijo also saw Amir Temur's wives, daughters-in-law and grandchildren, met him, saw life in the palace, the paradise city. For this reason, his "Diary" is of great importance in the study of the internal life of the state of Amir Temur, the history of his relations with European countries. The origin of Amir Temur, the general condition of the peoples and countries ruled by his ancestors, Amir Temur and his descendants, as well as the majestic palaces, mosques and madrasas, bazaars built by the order of Sahibkiran in the "Diary" of the keyboard rastas, valuable information about gardens.

Clavijo's Diary was published in Old Spanish in 1582 in Seville, Spain, two centuries later by Amirolo in 1779 and Antonio Sancho in 1782. The most valuable of these are the editions of
1582 and 1782. The work was republished in 1943 in Madrid by F. Lopez with the necessary commentary. This work of Clavijo was also translated into Russian, and in 1881 N.I. Sreznevsky, and in 1990 by IS Mirokova. The next edition is perfect.

Clavijo's "Diary" is undoubtedly one of the most invaluable historical sources on the life and world-famous historical services of Amir Temur. It is also highly valued and recognized in everyday historiography as a unique work. So, the trade and political relations between Timur and European countries in those years can be seen in many official documents. These are letters written between Timur and his third son, Mirza Mironshah (1393-1408), the ruler of western Iran, Iraq, Azerbaijan and the kings of France, England and other countries. Some of the letters are today housed in the famous British Museum and the National Library of Paris.

Clavijo writes about Samarkand and some of the buildings built by Amir Temur in it:About the wealth of Samarkand: "This country is rich in grain, wine, fruits, poultry, all kinds of meat everything costs a couple of fat sheep." (Ducat is the gold coin that was in use in Spain at that time).

About the big avenue and stalls: "Every year Samarkand sells goods from China, India, Tatarstan and other countries, as well as from the very rich Timur's empire. Until now, there was no large place to sell the goods brought to the city. The king ordered a street with a row of shops on either side. The street had to start at one end of the city go through the middle of the city and end at the other end. No matter who owned the houses, they were constantly destroyed. Shops have been built on both sides of the street, and high marble 
benches have been erected in front of each shop."

Clavijo also writes: "In June of this year (1404) a caravan of about 800 camels arrived in Samarkand from the city of Khanbalik."

Ordabozor: On the occasion of the big wedding, the king said: Let them go out into the plain and trade in tents and let every carpenter walk around the camp, and entertain the people with his merriment. " Then all the merchants left the city and settled around the king's residence. Each of the artisans organized a separate rasta, organized a military parade and walked around the camp."

About the palace of Kuksaroy and the workshop for the manufacture of weapons belonging to the king: "On the outskirts of the city there is a tower surrounded by a ditch with running water and the tower is an impassable fortress. lib was left. The king's treasury is kept in the palace which is why no one could enter except the judge and his officials. About a thousand artisan captives were housed here by order of the king. They make armor, helmets, bows and spears for the kingdom all year round. "

About the mobile mosque that Amir Temur took with him: "The ambassadors were led to the wooden house on the sarpard. It leads to a tall building via a staircase. It was surrounded by a wooden corridor and a glass porch. Finished in gold and blue the building was built in such a way that it could be torn down if necessary. It was a mosque where the king prayed and Amir Temur took it with him on his journey. "

About the way of life of the local people (he is called Clavijo Chigatoi): "He is a hardworking, skilled rider, archer and generally a people who are resilient in war. It is a nation that is content to live on bread and milk and meat, and to live on meat and non-meat. A nation more resilient and resilient than any other country in the world in enduring heat and cold, hunger and thirst. He eats too much meat and boils it with yogurt and water." .

Regarding one of the feudal obligations: "Temurbek divided his horses and sheep for one of his yasuvs to keep a thousand and for another ten thousand. If the king does not return the flocks at the request of the king, or if he returns the hooves less than he intended, the king will not accept any compensation, he will take everything, but he will execute the sinner." .

Regarding the status of women in the palace of Amir Temur: "On Thursday, October 23, 1404, the king gave another big wedding in the Horde and invited the ambassadors to him. There were a lot of guests at the wedding ... There was a lot of fun and joy. The king's wives, dressed as at previous weddings, were present, having fun with the men ..."

The image of the princes and the women in the palace of Amir Temur: The image of the prince's prince: The prince and the women in his presence were sitting under an umbrella in front of the big tent door ... He was celebrating the wedding of one of his relatives today."

The image of the Lady of the Palace: "After all the people had taken their seats and the arrangement had been made, the great Canaan, who was to be present at the wedding, came out of one of the saparas near the tents. This is what she was wearing: a long, wide-sleeved red silk dress with gold 
embroidery on the hem. The shirt, which had no open space except for the collar and two sleeves, was narrowed at the waist and widened to the skirt ... The skirt was carried by about fifteen women. The lady's face was covered with so much white powder to protect it from the sun that her face looked like white paper. All the noble women who travel in winter and summer apply such an oily powder on their faces. The lady wore a tall, red hat that looked like a helmet worn only in battle, with a thin white cloth thrown over her face. One end of it rests on the lady's shoulder. The red helmet is adorned with many large pearls, rubies, turquoise, and various other precious stones. The part of the hat that is still on the shoulder is sewn with gold, and it is decorated with a beautiful gold leaf decorated with precious stones and large pearls.

\section{DISCUSSION}

There are some inaccuracies, mistakes and shortcomings in the keyboard "Diary". Here are some of them: "It is said," wrote Clavijo, that Temurbek and four or five of his servants began to take sheep and cows from the neighboring houses one day and the next. Sometimes he would go to a party and entertain them with stolen sheep. Sometimes because of his courage and nobility, he gives all he has to his people and many people gather around him.

Eventually his cavalry reaches 300 . From then on, he traveled far with his cavalry to plunder and steal what he and his men needed, and he began to rob traders on the roads. " But there is no mention in any historical work about the life of the master that he was a thief and a thief. Chapter 107 of the Diary about the death of Chigatay and Chapter 147 about Khalil
Sultan's condition on the day of Amir Temur's death are also far from the truth.

In particular, Clavijo said that Chigatay was killed by the people of Samarkand, while Khalil Sultan was in Samarkand at the time of Timur's death. In fact, it is not. Chigatay died in 1242 on the Ili River, and Khalil Sultan was in Tashkent on the day of Timur's death. Another shortcoming of the play is the confusion in the spelling of person and place names. Of course, it is very difficult for a person of another nationality to pronounce local terms and words correctly. Amirat - Murad, Karil Sultan Khalil Sultan, Kirmanoli - Manuil Paleolog, Karamish - Tokhtamish, Miasha mirassa Mironshah Mirzo, Baldat - Baghdad, Kanbalek Khanbalik, Karras - Araks, Orasan - Khorasan mentioned in the "Diary" can be understood that. But there are also terms like Buamo, Talisia, Jagaro that can't be defined. However, the Comments at the end of this work make it relatively easy for the researcher to read Claviho's Diary.

\section{CONCLUSION}

In short, on a daily basis the play deals with the adventures of the Spanish ambassadors before their arrival in Samarkand, various events in the state of Amir Temur weddings important information about the ruler's harem, the origin and successors of Amir Temur. There is a description of Samarkand and other cities, the situation in the lands occupied by Timur the situation and occupation of the local population the structure of the state and the army and other valuable information. 


\section{REFERENCES}

1. Karimov I.A. High spirituality is an invincible force. Second edition. Tashkent .: Manaviyat, 2011.

2. Abdurazzoq Samarkandiy. Matlai sadayn and majmai bahrain / Translation from Persian-Tajik, introductory words and annotated dictionaries A. Oriboevniki. - $\mathrm{T}$.: Fan, 1969.

3. Amir Temur in world history / Business leader prof. S. Saidqosimov. - T : Sharq, 1996.

4. Amir Temur in world history. Completed and revised second edition. - T .: Sharq, 2000.

5. Amir Temu and his place in world history. - T .: Fan, 1996.

6. Bo'riev O. Central Asia in the written sources of the Timurid period. - $\mathrm{T}$.: Writer, 1999.

7. Ibn Arabshoh. The history of the wonderful al-maqdur fi Taymur / Foreword, translation and commentary from Arabic by $U$. Uvatov. - T .: Mehnat, 1992. I book.

8. Ibn Arabshoh. The history of the wonderful al-maqdur fi Taymur / Foreword, translation and commentary from Arabic by $U$. Uvatov. - T .: Mehnat, 1992. Book II.

9. Lunin V. B. Sources of Amir Temur and his period. - Tashkent: Encyclopedia, 1996.

10. Muhammadjonov M. Amir Temur and the Temurid Empire. - Tashkent: Encyclopedia, 1994.

11. Temur's rules / Prof. B. Edited by Ahmedov. - T .: Literature and art, 1991.
12. Rui Gonzales de Clavixo. Diary of a trip to Samarkand - Amir Temur Palace. (1403 - 1406). -Tashkent .: Uzbekistan, 2010.

13. Madraimov A., Fuzailova G. Source studies. - T., 2008.

14. Rui Gonzales de Clavijo. Diary of a trip to Samarkand - Amir Temur Palace. (1403 - 1406). -Tashkent: Uzbekistan, 2010.

15. History of Timur and Ulugbek. - T .: Encyclopedia editor-in-chief, 1996. 